\title{
LEVEL OF ACADEMIC AND DIDACTIC COMPETENCIES AMONG STUDENTS AS A MEASURE TO EVALUATE GEOGRAPHICAL EDUCATION AND PREPARATION OF STUDENTS FOR THE DEMANDS OF THE MODERN LABOUR MARKET
}

\author{
MaŁgorzata Cichoń, Iwona Piotrowska \\ Departament of Geography Teaching and Ecological Education, Adam Mickiewicz University in Poznań,
} Poland

Manuscript received: December 8, 2017

Revised version: January 16, 2018

\begin{abstract}
Cichó́ M., PiotrowsKa I., 2018. Level of academic and didactic competencies among students as a measure to evaluate geographical education and preparation of students for the demands of the modern labour market. Quaestiones Geographicae 37(1), Bogucki Wydawnictwo Naukowe, Poznań, pp. 73-86. 5 figs, 3 tables.
\end{abstract}

ABSTRACT: Young people, regardless of their social environment, place of residence or work, are looking for values and key competencies that enable achieving goals in life. Therefore, an appropriate education system is important, which in the conditions of changing reality will meet these requirements effectively. The contemporary employer is interested in four groups of key competencies, such as intellectual, professional, personal and interpersonal. Geography is a field with great potential for the development of various competencies. In this context, questions about adjusting geographical education to the expectations of employers are justified. Therefore, the aim of the study is to assess the strengths and weaknesses of the current development of competencies and qualifications at the geography speciality of the Faculty of Geographical and Geological Sciences, Adam Mickiewicz University in Poznań, Poland. The reference points included a report on research carried out among 200 employers in 2012, as well as surveys among students graduating from master's studies on the assessment of the level of their competencies and qualifications. It was determined that the strength of the current geographical education at the faculty is to prepare mainly specialists with broad general and professional knowledge, and high self-esteem in terms of cooperation in the group and communication. The area of development for the geographical education are intellectual competencies, above all independent thinking and prioritising. The last year geography students fall out the most in terms of personal competencies. The authors suggest building students' awareness because, as the above results show, they are not fully aware of what expectations they may face in the labour market. It is worth modifying the study program so as to put more emphasis on soft competencies and support the development of various forms of extra activities of students. Attention was also paid to the importance of didactic competencies, which on the one hand raise the self-esteem of students, and on the other, increase the chance of finding a good job. An interesting aspect of the research is the wide spectrum of professions in which students work. This reflects their diverse skills, including spatial thinking. Combined with increasing attention paid to the issues related to the natural environment and sustainable development, graduates of geography have a strong position to enter the current labour market. The advantage of geographers is the use of modern technologies. Unfortunately, however, the results of the research presented above, both among Polish students and internationally, indicate insufficient skills in the use of modern technologies by students of geography.

KEY WORDS: geographical education, evaluate competencies, labour market

Corresponding author: Małgorzata Cichoń, cichon@amu.edu.pl 


\section{Introduction}

The civilisation changes we are observing in the world, manifested by the development of new information and communication technologies, affect the functioning of modern people. The economy in which they function is based on knowledge, information and communication, and its basis is the education of graduates. Before well-educated graduates become indispensable in the process of creating social well-being (Harvey et al. 1997), they must face the changing labour market. They will be assessed by employers who will determine their employability (Little 2003). According to Little (2003) employability means a set of achievements, understandings and personal qualities that increase the probability of getting a job and succeeding in a chosen profession.

The changes taking place in the economy, from the local scale, through the regional to the global level, cause that academic education is seen by the prism of the labour market. According to Gedye et al. (2004), higher education is responsible for the prospects of employing its graduates as students have begun to function as clients. As Gedye et al. (2004) conclude, this is due to the higher costs incurred by students and their families for higher education. The need to find a wellpaid job to pay off debts and pressures for more graduates in the labour market competing at the graduate level means that prospective students are likely to make more informed decisions about where to study. Regardless of the social environment or place of residence, young people will seek out areas of study that will enable them to achieve their assigned competencies and, in the longer term, their professional goals.

Competency is a combination of knowledge, skills and attitudes appropriate to specific situations. Competencies enable, e.g. functioning in the modern world, they are needed for self-fulfilment, personal development, social integration, flexible adaptation to any change, and are decisive for success in adult life (Perrenoud 1997, Wspólnoty Europejskie 2007, Piotrowska 2011a, Cichoń, Piotrowska 2012).

According to Teichler (1997), even in the 1990s, it was assumed that getting education and becoming a productive member of society was the effect of three factors. These were economic conditions (the condition of the labour market, the level of innovativeness of the economy), individual factors (education of parents, sex, aspirations, motivation of graduates), and the accumulated education capital (field and program of studies, human resources and scientific research, involvement of the subject in the process of self-education). In the meantime, over the past three decades, as a result of growing competition in the global market, employers' expectations towards graduates have shifted. The modern-day employer of both large corporations and small businesses is interested in four groups of key competencies, such as intellectual, professional, personal and interpersonal. Qualitative results of studies on competencies are provided by a report (SGH, AmChe, E\&Y 2012) prepared by the SGH Warsaw School of Economics, the American Chamber of Commerce in Poland (AmCham) and Ernst \& Young, which included 200 companies. The most critical competencies in the opinion of the employers taking part in the study are effective communication, openness to learning and continuous development, activity and engagement at work, flexibility and adaptability, teamwork, foreign languages (mainly English), responsibility, ability to formulate and solve problems and use of information and communications technology (ICT). It implies that universities need to change their education strategies. Mass education in universities with low levels of state support, present for the past two decades, requires a different approach.

In the context of debates on the role of the university and the neoliberalisation of higher education, according to Walkington et al. (2017), it is worth to rethink which disciplines allow for the development of holistic thinking, interdisciplinary knowledge, and contribute to the growth and prosperity of societies. As far as the above authors are concerned, broader aims and values of this field in the context of individual human development should also be taken into account. Geographical thinking is of great educational importance. Using international examples of practice in the field of geography education, Walkington et al. (2017) list five geographical functions: developing geographical/spatial imagination, ethical approach to human impact on processes, integrated thinking on socio-environmental relations, exploration of places. According to Whalley et al. (2011), the potential 
of geography refers to the space and interpretation of the changes that may occur, which can be a unique product. This assumption should stimulate workers to continuously deepen and verify their knowledge and skills, particularly those related to ICT. What should be kept in mind is that in the coming years, a Digital Generation of teenagers will be entering the labour market (Tapscott 2008, Piotrowska 2011b). Piróg (2014), by literature analysis and empirical research on the situation of geographers on the Polish labour market as a result of mass higher education, indicates an increase in the percentage of geographers working contrary to their completed studies, similarly to the situation in other countries. It means that the challenge for the university is also to pursue lifelong learning (LLL) in a diverse, multicultural society.

In this situation, questions about the quality of geographical education and the level of adaptation of curricula and methods of education to the needs and expectations of one of the leading stakeholders of the university, i.e. employers, are justified. One of the elements of adapting universities to the needs of the labour market is systematic research conducted among graduates who can assess the suitability of particular subjects in their job (Clark, Higgitt 1997). It is also necessary to work with employers who, according to Tymon (2013), believe that graduates are not ready to work. Therefore, one of the requirements is to provide prospective employers with a program of studies for assessment in the field of competencies. Another document is the profile of the graduate. Extensive material in this area has been published, among others, by Osuch (2012).

At the Faculty of Geographical and Geological Sciences, Adam Mickiewicz University in Poznań, Geography students have the opportunity to develop two types of competencies (soft) and obtain qualifications (hard competencies). First, it is a general-purpose education, during which the graduate primarily understands and analyses the changes taking place in a dynamic natural environment, maps and analyses in the laboratory the elements of the environment, makes assessments and predicts changes in the state of the environment using Geographic Information System (GIS) and uses the latest mapping technologies and analysis of remote sensing data. The second is the teaching, preparing for the profession of a geography and natural science teacher. The goal of this education is to be independent in research, creative problem solving, teamwork, communication and presentation of results, planning of work and professional development, and entrepreneurship.

However, the primary goal of didactic education is to prepare students to work as a teacher. The didactics of geography, i.e. science about teaching and learning, is considered as an interdisciplinary, theoretical and practical science, which takes into account numerous utilitarian aspects (Piotrowska 2010). As science, didactics provides knowledge and analyses the relationships that shape the course and outcomes of the teaching and learning, and formulates the appropriate norms on that basis, and also provides methods, organisational forms, and means to support the intended changes in students. Also, it examines the elements and determinants of the geography teaching and learning process, determines the regularity of this process, and its organisation at various levels of education. The didactics of geography has a theoretical, diagnostic and prognostic, as well as practical function. In the research, according to Piskorz (1997), it considers indications of logic (e.g. in research on the development of concepts or types of reasoning); didactic ergonomics (e.g. in research on the organisation of the teaching of geography); praxeology (e.g. in research on problem geography teaching) and cybernetics (e.g. in research on programming in geography teaching).

In view of the lack of current literature on the assessment of the competencies of geography graduates, with the exception of Biernat (1997), Piróg (2012, 2014), Cichoń and Piotrowska (2012) and Osuch (2012), the study will assess the strengths and weaknesses of the current development of competencies and qualifications acquired by students finishing postgraduate (master) courses in geography at the Faculty of Geographical and Geological Sciences, Adam Mickiewicz University. The reference point will be the results of the SGH, AmChe, E\&Y (2012).

\section{Research methods}

The methodology included the survey conducted in spring 2014 among 120 students of the 
second year of the Master course in Geography. Formal requirements allowed to cover only 99 questionnaires in the further analyses. Due to the possibility of obtaining qualifications and competencies, the geography students of the faculty were divided into two groups: a general-purpose profile (37 persons) and a general geographical profile with the didactic module preparing for the profession of a geography teacher (62 persons).

The questionnaire comprised eight questions (both closed and open) regarding the degree of competency and qualification. According to Niemierko (2004), competency is defined as all the skills necessary to undertake and perform cognitive and practical activities in a particular field of education, personal and professional life. Skills include the sphere of interaction in the didactic process, while the competencies relate to the person, resulting from the integration of some skills learned and skilfully managed to achieve a free, intelligent, reflective and responsible action (Okońska-Walkowicz et al. 2009). Competency is seen as equipment of a person and the ability of the individual, acting as a higher order skill.

It is therefore assumed that the competencies are theoretical knowledge, practical skills, attitudes and personal qualities, while qualifications

Table. 1. Competencies and qualifications listed in a geography graduate profile.

General competencies of the last year student

Understands the systemic, dynamic character of the natural environment

Analyses the dynamics of environmental changes in different spatial and temporal scales

Maps and monitors elements of the environment

Conducts laboratory analyses of the air, water, sediments and soils

Draws and verifies environmental impact assessments

Forecasts the changes in the state of the environment using GIS techniques

Uses the latest technology for mapping and remote sensing analysis

Didactic competencies of the last year student

Carries out own scientific research and seeks information

Creatively solves problems

Efficiently and actively cooperates with the group

Communicates well in Polish and a foreign language

Effectively presents individual results and opinions

Plans and organises personal work and professional

development

Is entrepreneurial include the skills required to perform professional tasks (in a chosen speciality). They come from specific documents (certificates, diplomas, attestations) and create the presumption that a given person has the right competencies. The research focused on the self-assessment of students' mastery in seven competencies and the seven qualifications listed in a geography graduate profile (Table 1). It was also essential to identify what professions/occupations students perform at the end of their studies, and which competencies or qualifications are useful in their current job.

\section{Results}

The questionnaire survey allowed to determine that the students of the last year of the master's studies assessed their level of professional qualifications (general-geographical) with the average result of 3.5, with the higher self-assessment by the students participating in the didactic module (Fig. 1). The differences between the two groups of students are at 0.5 points. It has been observed that students highly assess their knowledge of the geographical environment and can analyse changes in the environment. Almost half of the respondents rated their qualifications in this area at 4.0. Some respondents rated their skills in mapping and environmental monitoring a bit lower. On an average, the students ranked at 3 out of 5 their skills in using modern technologies, forecasting and preparing impact assessments. For those skills, the most numerous group of $40 \%$ were the respondents with the grade 3 , and $30 \%$ are students with 4 and $20 \%$ of the surveyed population with 5 . The lowest score was given to the laboratory analyses, as almost $30 \%$ of students rated their level at 1 and 2 points.

In the field of didactic competencies, the situation looks a little better, because the students rated higher their teaching competencies than professional/general skills. However, there are no significant differences between competencies. The students self-assessed highest their professional development and teamwork (Fig. 2). At 3.7 points students assessed their entrepreneurship, presenting results, solving problems and communicating. The most unsatisfactory results were gained by independence in conducting research. And for the second time, it was observed 


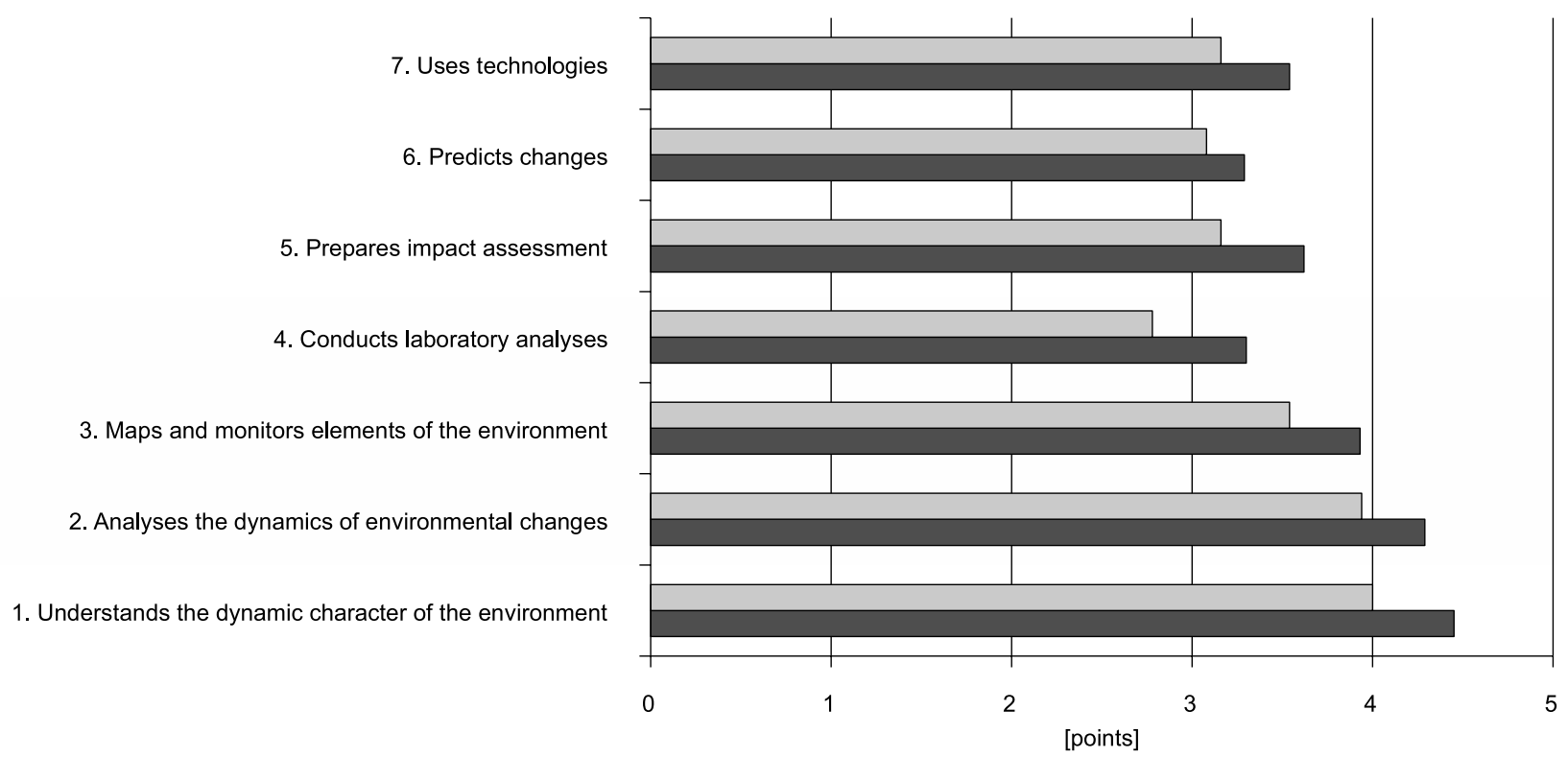

a general geographical profile $\quad \square$ a general geographical profile with the didactic module

Fig. 1. Assessment of the level of professional qualifications (general-geographical) of the students of the last year of master's studies.

that students from the didactic module rated their competencies higher, and the most significant difference was 0.58 points for the ability to present results.

The conducted research allowed to compare the self-assessment of students in the field of soft and hard competencies with the competencies of the ideal graduate of a higher education institute presented in the Report prepared, among others, by SGH Warsaw School of Economics (SGH, AmChe, E\&Y 2012). On this basis, four groups of competencies were allocated (Table 2).

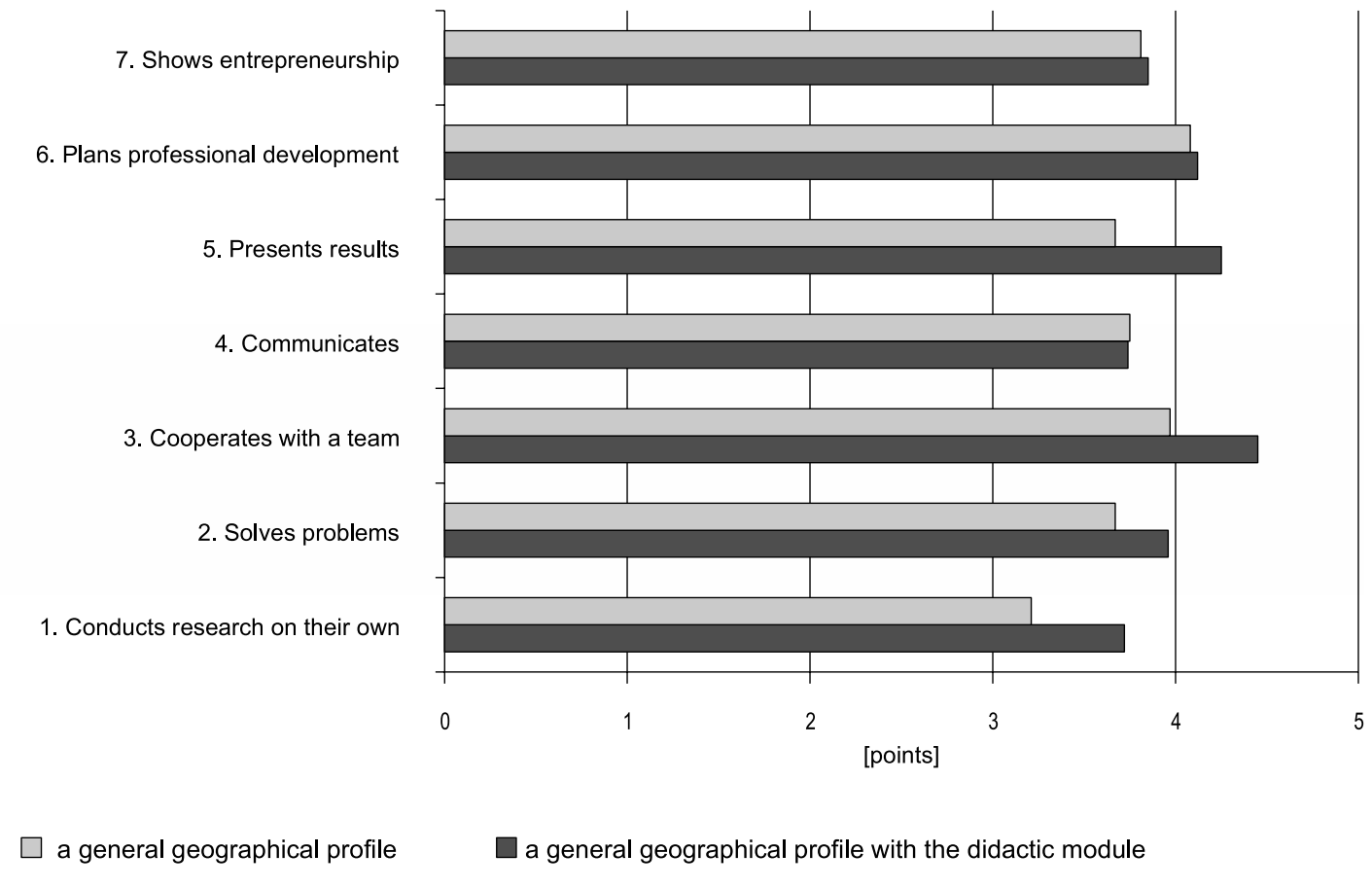

Fig. 2. Assessment of the level of didactic competencies of students of the last year of master's studies. 
Table 2. Comparison of self-assessment of AMU students of geography in the field of academic and didactic competencies with the assessment of employers.

\begin{tabular}{|l|c|c|c|c|}
\hline \multirow{2}{*}{ Competencies } & Assessment of grad- & \multicolumn{2}{c|}{ Student self-assessment } & Usefulness \\
\cline { 3 - 5 } & uates by employers & $\begin{array}{c}\text { a general geographical pro- } \\
\text { file with the didactic module }\end{array}$ & $\begin{array}{c}\text { a general-pur- } \\
\text { pose profile }\end{array}$ & $\begin{array}{c}\text { number } \\
\text { of students }\end{array}$ \\
\hline Technologies & 3.94 & 3.54 & 3.16 & 4 \\
\hline Communication & 3.74 & 3.74 & 3.75 & 17 \\
\hline Cooperation & 3.69 & 4.45 & 3.97 & 8 \\
\hline Problem-solving & 3.56 & 3.96 & 4.08 & 4 \\
\hline Planning for development & 3.35 & 4.12 & 3.21 & 0 \\
\hline Self-reliance & 3.47 & 3.72 & 3.81 & 9 \\
\hline Entrepreneurship & 3.19 & 3.85 & 3.67 & 0 \\
\hline Presentation & 3.0 & 4.25 & 3.97 & 12 \\
\hline $\begin{array}{l}\text { Knowledge about the environ- } \\
\text { ment }\end{array}$ & no data & 4.37 & 3.31 & 2 \\
\hline Fieldwork and prognosis skills & no data & 3.61 & 2.97 & 2 \\
\hline Specialist skills & no data & 3.46 & no data & 0 \\
\hline Flexibility and adaptability & 3.8 & no data & no data & 7 \\
\hline $\begin{array}{l}\text { Foreign language skills (mainly } \\
\text { English) }\end{array}$ & 4.1 & no data & & 2 \\
\hline
\end{tabular}

Average rating of competencies on a scale from 1 - very poor, to 5 - very good.

Source: SGH, AmChe, E\&Y (2012).

The first group is the competencies (didactic/ soft) that are expected by the employer and at the same time are developed at the faculty of geography. It is the ability to: formulate and solve problems, work in a team, communicate effectively and plan for development. In this group, students' self-assessment was higher than the average reported by employers. This first group also included skills related to qualifications such as the use of ICT tools. The self-assessment in those terms was lower than the average employer rating.

The second group is the (didactic) competencies, which are developed at the geography department but fall within the scope of another competency mentioned by the employer. For example, the pursuit of results may stem from entrepreneurship, and commitment from self-reliance and responsibility comes when presenting results. In this group of competencies, the student self-assessment was higher than the average rating of employers.

The third group consists of professional geographically-oriented qualifications, developed at the department of geography, but the interest in these competencies among employers is low because they are related to narrow specialities, such as a laboratory analyst or environmental specialist.

The fourth group of competencies identifies the competencies (didactical) that are expected by the employers but are not present in the graduate profile.

In the academic year $2013 / 2014,60 \%$ of students in geography pursued a job, with almost $30 \%$ finding it in commerce, while $20 \%$ in professions connected with their majors, such as surveyor, analyst, database specialist and nearly $15 \%$ as office workers. Another $15 \%$ in the group of working students were physical workers. Least students were employed in pedagogical professions; single persons worked as a translator, photographer and electrician. A similar proportion of students working in the profession is recorded at the speciality of tourism and recreation. According to research conducted by Piotrowski et al. (2016), 43\% of students of tourism and recreation undertake paid work in tourism occupations (Fig. 3).

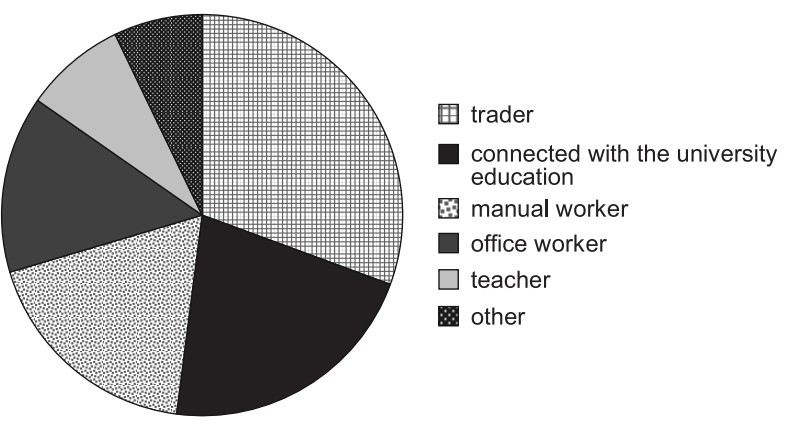

Fig. 3. Share of students of the last year of studies in the structure of employment. 


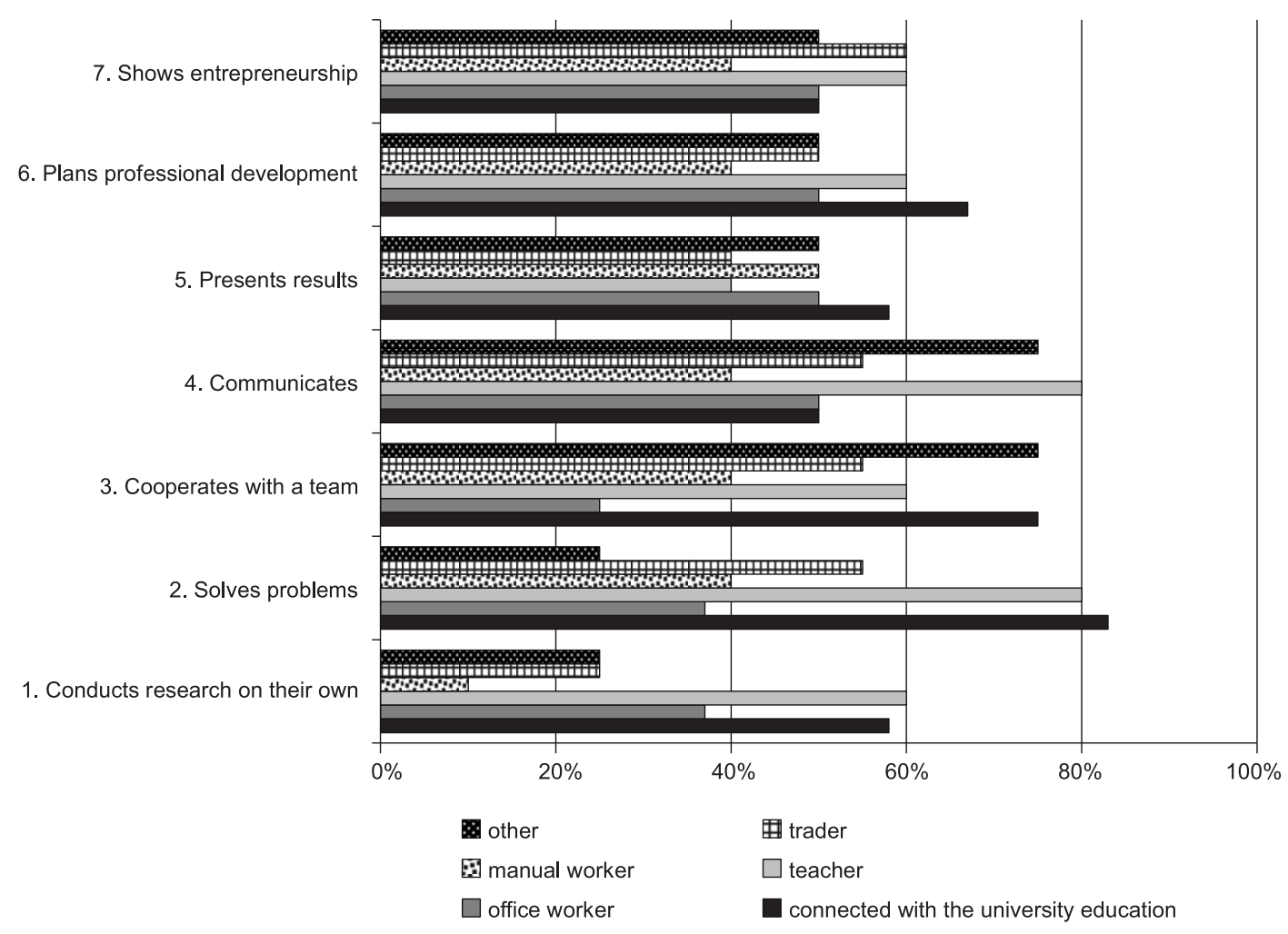

Fig. 4. Assessment of the usefulness of selected didactic competences - general geographic (hard) in the current work in the opinion of the surveyed students.

On the basis of the research, it was found that the soft (didactic) competencies were most useful. The most critical competency in all professions was the ability to communicate, solve problems and cooperate in the group, while at the same time, the independence of research was least significant. Students agreed that what is needed in all the professions is entrepreneurship, the ability to present their ideas or plan their professional development.

The assessment of the usefulness of professional (geographical) knowledge and skills in the

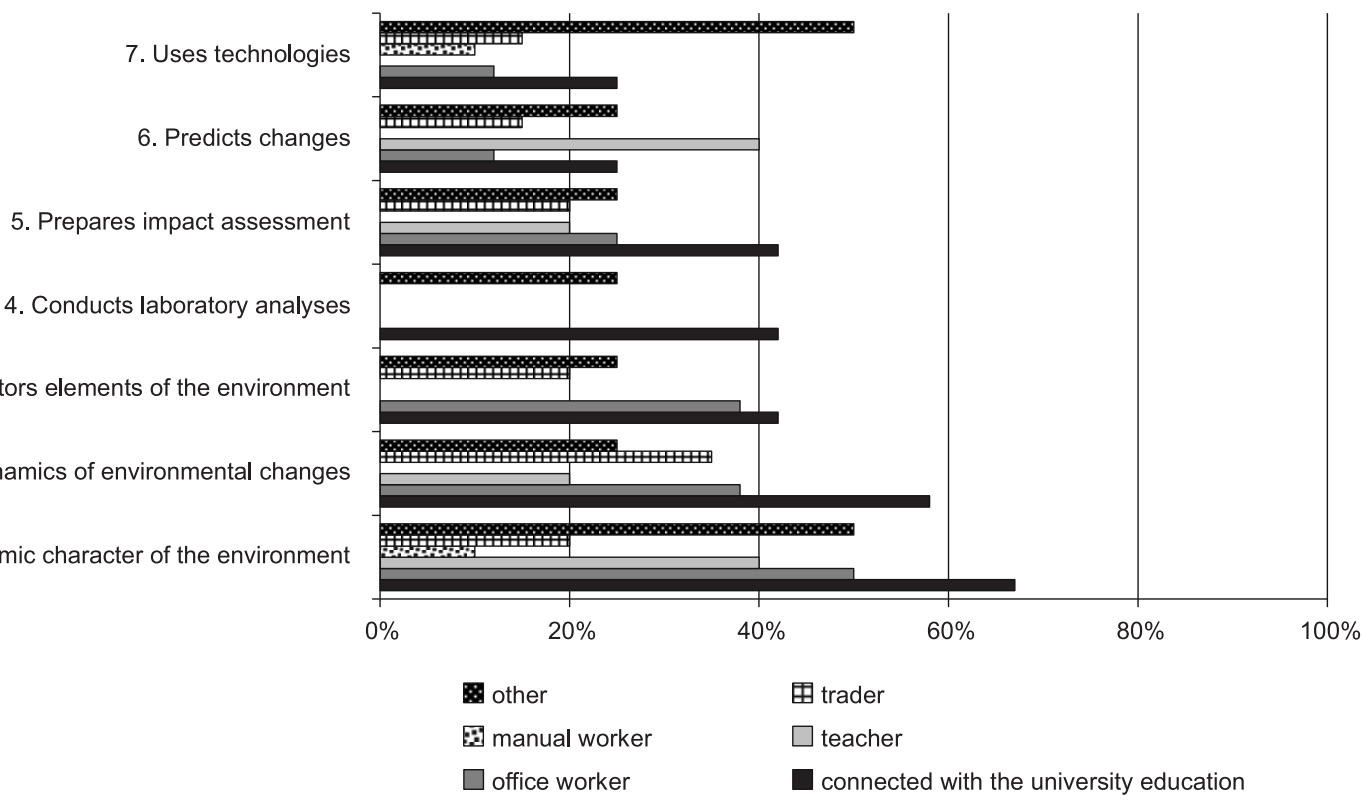

Fig. 5. Assessment of the usefulness of selected academic competences - general geographic (hard) in the current work in the opinion of the surveyed students. 
current work leaves no doubt that they are needed primarily in directional jobs, including office workers and educators. In turn, as of little use in present employment, students mention conducting laboratory analyses or mapping the environment. The use of modern technologies is also not very useful, but people working in other professions are of a different opinion in this respect.

\section{Discussion}

At the beginning of the $21^{\text {st }}$ century, in the era of super-competencies, one should once again look at education programs through the prism of employers' requirements resulting from the needs of the labour market. Geographical programs are inherently diverse, which is associated with interdisciplinary thinking and geographical skills.

Analysing students' self-assessment and records in the graduate profile, one can conclude that the strength of current geographical education at the Faculty of Geographical and Geological Sciences of the Adam Mickiewicz University in Poznań, is to prepare specialists with broad general and professional knowledge, similarly to other Polish and Czech universities, as mentioned by Osuch (2012). By proposing a variety of classes at the university, planning skills and entrepreneurship are indirectly developed among students. Instead, students are explicitly taught how to use modern technologies (Table 2, Table 3). Students' self-assessment in this field leaves no doubt. They do not feel prepared enough to work using ICT. It may result from high expectations of students in the use of specific computer programs or the experience of employers with very well-educated graduates. However, if these assessments are analysed from the perspective of geography students, it turns out that the potential attributed to geography as a science is not fully exploited in this field. A good example of the strengthening of geography through GIS are geographical studies programs in Spain (de Miguel González, de Lázaro $y$ Torres 2016). The field of geography with the speciality of geoinformation has been present at Adam Mickiewicz University for several years. However, the records in the documents and the students' self-assessment inform about the greater emphasis on geographical knowledge and skills than the use of modern technologies. It is worth noting that both geographical knowledge and the use of ICT are fundamental. Wellestablished knowledge and skills can be a big advantage of the graduate because although the final grades on the diploma are not important for the employer, they look at them through the prism of the person's involvement and potential. Therefore, the educational process should not be underestimated, and students who say that specialist knowledge will be essential in the future show high awareness. Already, employers in the report emphasised that in addition to basic expert knowledge, a graduate should have basic management skills, e.g. in the field of project management, small teams and a good knowledge of at least one foreign language.

The high point of education in the field of geography is the top students' self-assessment in such skills as cooperation in a group and communication, including the presentation of results and opinions (Table 2, Table 3). These three skills belong to the group of interpersonal competencies and are rated by students at the level of 4 out of 5 points. It can be concluded that geography students are well prepared in this area. In recent years, the ability to cooperate with people from different backgrounds, countries and religions, functioning in an international environment has been emphasised. Therefore, openness to other cultures, solutions, methods of communication and work is an indispensable feature. Due to geographical themes, a participation of foreigners in the process of university education and numerous trips abroad, students should not have problems in this area. Especially nowadays, intercultural diversity creates opportunities for a better understanding and cooperation with other people. In geography, the notion of cultural circles, determined by geographical location, combines specific cultural features and elements relating to language, religion, material culture and the level of social and technological development that formed as a result of several hundred years of evolution. Understanding cultural circles will allow students to understand different perceptions of the world and other values that guide their members. In this context, the challenge is geographical education at various levels, which will enable learning and understanding of this diversity (Piotrowska, in press). 
Table 3. List of skills mentioned by employers as priorities and skills mentioned in department documents.

\begin{tabular}{|c|c|}
\hline Skills mentioned by employers as priority & $\begin{array}{l}\text { Skills mentioned in department } \\
\text { documents }\end{array}$ \\
\hline Personal skills & \multirow[t]{13}{*}{ conducts own research } \\
\hline 1. Ethical behaviour as a basis for action & \\
\hline 2. Responsibility & \\
\hline 3. Commitment & \\
\hline 4. Loyalty and willingness to be connected with the company for a longer time & \\
\hline 5. Openness to learning and constant development & \\
\hline 6. Striving to achieve results & \\
\hline 7. Independence & \\
\hline 8. Ability to work under time pressure & \\
\hline 9. Correct self-evaluation. Understanding own strengths and limitations & \\
\hline 10. Flexibility and adaptability & \\
\hline 11. Ability to make decisions & \\
\hline 12. Empathy & \\
\hline Interpersonal skills & \multirow{6}{*}{$\begin{array}{l}\text { presents results, opinions, commu- } \\
\text { nicates, works in a group }\end{array}$} \\
\hline 1. Effective communication & \\
\hline 2. Ability to work in a team & \\
\hline 3. Ability to cooperate with people from different backgrounds, etc. & \\
\hline 4. Ability to collaborate with people in high positions & \\
\hline 5. Negotiation skills & \\
\hline Intellectual ability & \multirow[t]{6}{*}{ solves problems } \\
\hline 1. Ability to think logically & \\
\hline 2. Creativity & \\
\hline 3. Ability to think independently & \\
\hline 4. Ability to formulate and solve problems & \\
\hline 5. Ability to define and justify priorities & \\
\hline General and professional skills and knowledge (hard/expert knowledge) & \multirow{12}{*}{$\begin{array}{l}\text { uses modern technologies, plans } \\
\text { professional development, pro- } \\
\text { fessional knowledge and skills, } \\
\text { enterprising }\end{array}$} \\
\hline 1. Numerical skills & \\
\hline 2. Knowledge of foreign languages & \\
\hline 3. Ability to organise work and effective time management & \\
\hline 4. Ability to manage projects & \\
\hline 5. Ability to use ICT tools & \\
\hline 6. General knowledge & \\
\hline 7. Expert knowledge & \\
\hline 8. Analytical skills & \\
\hline 9. Professional experience & \\
\hline 10. Entrepreneurship & \\
\hline 11. Diplomas, certificates & \\
\hline
\end{tabular}

Source: SGH, AmChe, E\&Y (2012).

The area of development for the geographical education is intellectual competencies; however, it is not about knowledge but the ability to think logically and independently, creativity, the ability to formulate and solve problems and the ability to define and justify priorities (Table 2, Table 3). Among these five skills of a geography graduate important for employers, one can only find the ability to solve problems. Self-assessment of students in this area is 3.8/5 points, while that of the employers 3.6. It is worth emphasising that the basis of geographical sciences is the analysis of the occurring cause and effect relationships, which allows the development of logical thinking. The lack of such an element in the graduate's program or profile does not mean that geography students are deprived of such reasoning. The problem may arise, however, with independent thinking or determining priorities.

The last year geography students fall out the most regarding personal competencies (Table 2, Table 3), which are the key criteria for recruitment of over $30 \%$ of employers. During the interviews, employers pay particular attention to the 
need for flexibility and adaptability. It is related to the fact that change has become an inseparable element of today's organisations. It applies, among others, undertaking new tasks and responsibilities, adapting work methods and priorities to the changing market circumstances and changes within the structure, as well as mobility. Meanwhile, the graduate profile mentions only independence. Respondents in their questionnaires indicated the usefulness of such features as diligence, punctuality and conscientiousness. In turn, for the employer, ethics, loyalty, responsibility and empathy are more important among personal skills. A different perception of the employer and graduate concerning these features may result from various perceptions and outdated educational concepts. Once, attention was paid to child's diligence, while today's employee should be more empathic and loyal than punctual. According to employers, graduates lack humility and positive self-esteem, they expect a quick career without effort or self-denial. One can disagree with such an image of an employee, however, in the current conditions of mass education at the university, the labour market for newly promoted graduates is the employer's market.

There are many areas and competencies in which employers are not satisfied with the preparation of graduates, and the quality of education of graduates has been declining for several years. However, one cannot generalise and agree with Tymon (2013) that graduates do not have basic skills or are not ready for work. Even if there are such graduates, all efforts must be made to help them. Three basic recommendations for the university can be helpful in this regard.

Employers propose to bring together two worlds (universities and businesses) by engaging business representatives to conduct specific classes, including those regarding building student awareness regarding the specificity of working in different company profiles. Building awareness is crucial because, as the above results show, students are not fully aware of the expectations they may face in the labour market. Among the competencies preferred by employers, students primarily mentioned communication, technologies, cooperation and knowledge of a foreign language. Few respondents understand the importance of the ability to solve problems and plan own development. None of the respondents indicated flexibility and adaptability in the questionnaire. However, according to young employees, it is internal motivation and commitment, openness to learning, gaining different experiences and communication skills are the decisive factors for achieving success. Lack of awareness among geography students at the Nicolaus Copernicus University in Torun regarding the position of geographers on the labour market was also mentioned by Gierańczyk and Duży (2012). The authors, however, emphasise the small number of respondents and suggest that these results should not be generalised.

The second proposal concerns the modification of study programs to place greater emphasis on soft competencies. The results of a study conducted among 257 geography graduates of the Justus Liebig University in Giessen in Germany inform that traditional curricula do not necessarily prepare German geographers for work adequately. Graduates possess more knowledge than the company requires, but they do not have the competencies that the labour market needs. According to Hennemann and Liefner (2010), the solution may be the implementation of classes through, for example, the project method. According to Cichon and Piotrowska (2012), the combination of project method, geographical essay and review is an effective strategy for shaping key competencies. The students master the competencies of independent learning and communication on a high level, which is confirmed by the geographical essays and reviews, while gaining the low level of entrepreneurship competency.

In turn, participation in research projects makes it possible to develop all the competencies under study, but at a more diversified level. The type of method used and the involvement of students determine the level of competencies to a large extent. From the effectiveness of the education process, it is important to combine different teaching methods, because it increases the probability of developing various competencies at a higher level. Of a similar opinion are employers who recommend using group work, discussions, case studies or even self-study. It is worth thinking about a particular freedom in choosing subjects and lecturers while studying or attending classes from other areas than geography. Making free choices teaches students responsibility and flexibility. There are studies in the literature on 
the design of geographical programs based on a variety of geographical knowledge measures, technical competencies and personal qualities required by graduates (including Arrowsmith et al. 2011).

Finally, universities should explicitly support the development of various forms of extra-scientific activity of students. Employers are more willing to engage active graduates with passion and experience in student, social and sports activities. Multiple experiences can be gained, e.g. during work abroad, participation in a student exchange, activities in organisations and student clubs, scientific clubs. According to Simiyu et al. (2015), the majority of students can use the knowledge and skills gained in developing new competencies, planning a career path or establishing contacts with potential employers. Thanks to professional practices and internships, most students look at their career more optimistically.

The implementation of the above three recommendations may cause higher education institutions to take on the burden of real preparation of graduates. So far, particular fields of study, including geography, prefer training specialists. Since graduates of geography do not always work in geographical or related professions, this strategy does not seem to be good enough. However, observing the situation in western or northern Europe, it can be stated that the percentage share of students employed in non-geographical occupations is similar to that in Poland. Gedye et al. (2004) list professions where geography graduates from British universities work. These include administration, cartography, civil service, local authorities, environmental agency, human resources, IT, management, marketing, military, airline piloting, police service, research and retail. This broad spectrum of employment areas reflects the diverse skills that geography graduates have. On the other hand, Gedye et al. (2004) claim that rigorous intellectual training is in itself an excellent basis for entering the world of work. The study by Rothwell et al. (2002) shows that the majority of students choose to study geography because of the interdisciplinary nature of the field and geographical skills, rather than the belief in specific career opportunities. Whalley et al. (2011) consider, in turn, that geography for students offers broad and varied academic experience along with the knowledge that is updated by researchers in the context of civilisation change.

Research carried out by Gedye et al. (2004) show that in the labour market, geography graduates are better than graduates of other majors, because studying such a diverse scientific discipline provides the basis not only for the development of logical thinking but also for flexibility and adaptation to learn about and understand changes in the natural, social and economic environment. Graduates also have a look at the economy from a global, international perspective. According to Solem et al. (2008) a professional geographer, regardless of specialisation, is characterised by high competencies in the field methods, ability to work within the limits of discipline and spatial thinking. Combined with increasing attention to issues related to the natural environment and sustainable development as well as spatially-oriented technical skills of GIS, remote sensing and geodemography, geography graduates have a strong position to enter the current labour market. The advantage of geographers is the use of modern technologies.

Unfortunately, the results of research presented above, both among Polish students and internationally, indicate insufficient skills in the use of modern technologies by students of geography. A study by Clark and Higgitt (1997) showed that, on the one hand, students want less time to use modern technologies, which Tomlinson (2008) explains with low awareness of students treating their academic qualifications as irrelevant in taking up employment. On the other hand, graduates underline the insufficient number of hours in the use of ICT. In this situation, the potential of geographical sciences inherent in the possibilities of using modern technologies for the spatial development of phenomena is enormous and imposes specific tasks on the departments educating geographers.

The presented research results inform that the education of geographers at the Faculty of Geographical and Geological Sciences at Adam Mickiewicz University is carried out under the adopted assumptions of contemporary education in the field of substantive and technological preparation. The primary aspect of education is the ability to understand the functioning of the geographical environment, the use of GIS in 
research, problem-solving and the ability to work in a group. It should be noted, however, that master's studies provide students with the opportunity to develop competencies only in a narrow scope. It is confirmed by works from recent years, including Solem et al. (2013). According to these authors, there are many organisational and business skills that employers value, but which are not common in geography study programs.

It is worth returning here to one crucial issue - the results of students in two research groups. One can see higher self-esteem among students taking part both in the general academic profile and in the didactic module. The results show that the level of competencies in this group of students is higher. It may result from proper preparation for the teaching profession, but above all in the emphasis on didactic/soft competencies. Practical classes supplemented with pedagogical practices of 150 contact hours, considerably develop students, first of all in the field of time and group management, presenting opinions to the class, flexibility and adaptation to new situations in the classroom. Teachers are increasingly demanded to show empathy, independence, creativity and responsibility. Based on observations and interviews with students and employers, it can be concluded that students completing the didactic module have a better chance of employment. More often than graduates without didactic preparation, they manage projects and small teams. It is confirmed by previous studies by Piróg, Piróg (2007). However, research carried out by Gierańczyk and Duży (2012) confirms that all students of the Nicolaus Copernicus University graduating from geography with pedagogical preparation are convinced about increasing their chances of employment thanks to acquired didactic qualifications. Therefore, this can be the basis for inquiries about shaping the teaching competencies of other students. Paraphrasing the question asked by Chalkley et al. (2000), it is necessary to consider to what extent departments are responsible for the quality of education also concerning teaching competencies. Maybe it is worth taking an example from universities such as the University of Macquarie, where the vocational education was introduced to geography education (Dowling and Ruming 2013) and include didactic subjects to the whole course of geography.

\section{Conclusion}

In the academic education of the $21^{\text {st }}$ century, it is essential to strive for the development of soft and hard competencies (Piotrowska 2011a, Cichon, Piotrowska 2012). The university should create the opportunity to develop such competencies and qualifications that will allow the graduate to find a job and achieve financial independence. The presented research results show that geography education at the Faculty of Geographical and Geological Sciences at Adam Mickiewicz University in Poznań takes place in accordance with the adopted assumptions of contemporary education in the field of substantive and technological preparation. The fundamental aspect of education is the ability to understand the functioning of the geographical environment, the use of GIS in research, problem-solving and the ability to work in a group. Students highly assess their competencies. However, the weakest point is the use of modern technologies and low awareness of personal competencies that are most important in the contemporary world. It should be noted that master's studies provide students with the opportunity to develop competencies in a wide range of skills. According to Solem et al. (2013), there are many organisational and business skills that employers value, but which are not common in geographical programs. Therefore, higher education institutions should take better account of employers' recommendations to increase the share of companies satisfied with the recruitment of graduates and reduce the skills gaps expected by employers. It can be done in particular by regular research on expectations, periodic scientific conferences with partners and prospective employers of university graduates. It can also be assumed that the research on the labour market situation of university graduates will not change significantly until among the employers and in Polish society persuasion (supported by sound experience) persists, as is the case in Western countries, that bachelor studies prepare full-fledged graduates.

It seems that geographical study programs could address these problems by:

- regular surveys of former students' views and, where appropriate, adaptation of curricula;

- increasing the accessibility and information on skills and performance in lifelong learning in programs, modules and evaluation; 
- helping students recognise and appreciate skills they are developing which are valuable to potential employers.

The employment of university graduates is a problem in higher education, as labour markets are changing faster and faster. It is important for many fields, including geography.

\section{References}

Arrowsmith C., Bagoly-Simó P., Finchum A., Oda K., Pawson E., 2011. Student Employability and its Implications for Geography Curricula and Learning Practices. Journal of Geography in Higher Education 35: 365-377.

Biernat M., 1997. Losy zawodowe absolwentów geografii na tle losów absolwentów Wydziału Matematyczno-Przyrodniczego WSP w Kielcach w latach 1990-1995. Studia Kiel. Ser. Geolog.-Geograficzna nr 2.

Chalkley B., Fournier E.J., Hill A.D., 2000. Geography Teaching in Higher Education: Quality, assessment and accountability. Journal of Geography in Higher Education 24: 238-245.

Cichoń M., Piotrowska I., 2012. Kształtowanie kompetencji kluczowych wśród studentów geografii poprzez metodę projektu, esej geograficzny i recenzję. In: Z. Podgórski, E. Szkurłat (eds), Wybrane problemy akademickiej i szkolnej edukacji geograficznej. Prace Komisji Edukacji Geograficznej PTG, Łódź-Toruń, 2: 151-168.

Clark G., Higgitt M., 1997. Geography and lifelong learning: A report on a survey of geography graduates. Journal of Geography in Higher Education 21: 199-213.

de Miguel González R., de Lázaro y Torres M.L. 2016. Educating geographers in Spain: geography teaching renewal by implementing the European Higher Education Area. Journal of Geography in Higher Education 40: 267-283.

Dowling R., Ruming K., 2013. Synergies between geography, planning and vocationalism in curriculum development and implementation. Journal of Geography in Higher Education 37: 204-219.

Gedye S., Fender E., Chalkley B., 2004. Students' Undergraduate Expectations and Post-graduation Experiences of the Value of a Degree. Journal of Geography in Higher Education 28: 381-396.

Gierańczyk W., Duży W., 2012. Zawód geograf - atrakcyjność studiów geograficznych a przydatność na rynku pracy (w opiniach studentów kierunku geografia na wydziale Biologii i Nauk o Ziemi UMK). In: Z. Podgórski, E. Szkurłat (eds), Wybrane problemy akademickiej i szkolnej edukacji geograficznej. Prace Komisji Edukacji Geograficznej Polskiego Towarzystwa Geograficznego, 2: 113-134.

Harvey L., Moon S., Geall V., 1997. Graduates' Work: Organisational Change and Student Attributes. Birmingham: Centre for Research into Quality, University of Birmingham.

Hennemann S., Liefner I., 2010. Employability of German Geography Graduates: The Mismatch between Knowledge Acquired and Competences Required. Journal of Geography in Higher Education 34: 215-230.

Little B., 2003. International Perspectives on Employability Enhancing Student Employability Coordination Team (ESECT) $\&$ Centre for Higher Education Research and Information (CHERI) at the Open University. Online: www.ltsn.ac.uk/ genericcentre/index.asp?id=18285, (accessed April 2003)
Niemierko B., 2004. Cele kształcenia. In: K. Kruszewski (ed.), Sztuka nauczania. Czynności nauczyciela. Warszawa, 28 ss.

Okońska-Walkowicz A., Plebańska M., Szaleniec H., 2009. O kompetencjach kluczowych, e-learningu i metodzie projektów. Wydawnictwa Szkolne i Pedagogiczne Spółka Akcyjna.

Osuch W., 2012. Sylwetka absolwenta studiów geograficznych a jego kompetencje (studium porównawcze). In: Z. Podgórski, E. Szkurłat (eds), Wybrane problemy akademickiej i szkolnej edukacji geograficznej. Prace Komisji Eduakcji Geograficznej t.2 : 171-191.

Perrenoud Ph.,1997. Construire des compétences dès l'école. Paris: ESF.

Piotrowska I., 2010. Rola dydaktyki geografii w kształceniu twórczego nauczyciela. (Role of geography didactics in educating a creative teacher). In: A. Kwatera, P. Cieśla (eds), Rola i zadania dydaktyk przedmiotowych w ksztatceniu nauczycieli. (Role and tasks of subjects' didactics in educating a teacher.) UP, Kraków: 136-144.

Piotrowska I., 2011a. Influence of education transformation on improving key competence in geography teaching. Prace i Studia Geograficzne, Warszawa, 48: 27-40.

Piotrowska I., 2011b. Pokolenie cyfrowe w szkole XXI wieku. PEDAGOGIA. Wydawnictwo NAKOM, Poznań, 8: 4549.

Piotrowska I., in press. Geograficzne kształcenie w poznawaniu i rozumieniu zróżnicowania kulturowego na świecie (kręgi kulturowe, geografia myślenia). In: J. Rodzoś, E. Szkurłat (eds), Edukacja geograficzna wobec problemów wspótczesnego świata. Prace Komisji Edukacji Geograficznej PTG, 7, Lublin.

Piotrowski K., Rogowski M., Kosińska A., Zdebko J., 2016. Monitorowanie losów zawodowych absolwentów kierunku turystyka i rekreacja Uniwersytetu im. Adama Mickiewicza w Poznaniu. In: A. Zajadacz (ed.), Od Centrum do Katedry Turystyki i Rekreacji. Tom jubileuszowy w 70. Rocznice urodzin Profesora Zygmunta Młynarczyka. Turystyka i Rekreacja - Studia i Prace 19: 175-195.

Piróg D., 2012. Aspiracje i plany zawodowe młodzieży akademickiej w Polsce na przykładzie studentów geografii. In: A. Dudak, K. Klimkowska, A. Różański (eds), Przygotowanie zawodowe młodych pedagogów. Wyd. Impuls, Kraków: 125-144.

Piróg D., 2014. Pierwsza praca po studiach: oczekiwania osób kończących edukację akademicką stan rzeczywisty na przykładzie absolwentów kierunku geografia. In: D. Kotlorz (ed.), Edukacja w świetle przemian wspótczesnego rynku pracy - wybrane problemy. Studia Ekonomiczne nr 197/14.

Piróg D., Piróg S., 2007. Pożądane umiejętności absolwentów nauczycielskich studiów geograficznych na rynku pracy $\mathrm{w}$ procesie przemian społeczno-gospodarczych $\mathrm{w}$ Polsce. In: J. Lach, M. Borowiec, T. Rachwał (eds), Procesy transformacji społeczno-gospodarczej i przyrodniczych struktur przestrzennych. Wyd Naukowe AP, Kraków.

Piskorz S., 1997. Zarys dydaktyki geografii. (wydanie II zmienione). PWN, Warszawa.

Rothwell K., Fantom P., Owen K., Mok P., Christie F., Laing D., Gee D., Russell S., Done J., 2002. What do Graduates do? Career Planning for Higher Education and Beyond-2003 (Manchester: Higher Education Careers Service [CSU] and Association of Graduate Recruiters [AGR].

SGH, AmChe, E\&Y [SGH Warsaw School of Economics, the American Chamber of Commerce in Poland, Ernst \& Young], 2012. Kompetencje i kwalifikacje poszukiwane przez 
pracodawców wśród absolwentów szkót wyższych wchodzacych na rynek pracy. Online: firma.sgh.waw.pl/pl/Documents/RKPK_raport_2012.pdf (accessed 30.01.2018).

Simiyu R.R., Okaka F.O., Omondi P., 2015. Geography students' assessment of internship experience at a Kenyan university. Journal of Geography in Higher Education 39: 343-355.

Solem M., Cheung I., Schlemper M.B., 2008. Skills in Professional Geography: An Assessment of Workforce Needs and Expectations. Journal of Geography in Higher Education 60: 356-373.

Solem M., Kollasch A., Lee J., 2013. Career goals, pathways and competencies of geography graduate students in the USA. Journal of Geography in Higher Education 37: 92-116.

Tapscott D., 2010. Grown Up Digital and the Transformation of Learning. Online: dontapscott.com/books/ grown-up-digital/ (accessed 30.01.2018).

Teichler U., 1997. Higher Education and Graduate employment in Europe. TSER Research Paper 1997, p. 17.
Tomlinson M., 2008. 'The degree is not enough': students' perceptions of the role of higher education credentials for graduate work and employability. British Journal of Sociology of Education 29: 49-61.

Tymon A., 2013. The student perspective on employability. Studies In Higher Education 38: 841-856

Walkington H., Dyer S., Solem M., Haigh M., Waddington S., 2017. A capabilities approach to higher education: geocapabilities and implications for geography curricula. Journal of Geography in Higher Education: 1-18.

Whalley W.B., Saunders A., Lewis R.A., Buenemann M., Sutton P.C., 2011. Curriculum Development: Producing Geographers for the 21st Century. Journal of Geography in Higher Education 35: 379-393.

Wspólnoty Europejskie, 2007. Kompetencje kluczowe w uczeniu się przez cate życie, Europejskie Ramy Odniesienia. Online waloryzacja.llp.org.pl/sites/waloryzacja.llp.org.pl/ files/keycomp_pl.pdf (accessed 26.01.2018). 